\section{More money needed for human genome mapping project}

\section{Bethesda}

THE Reagan Administration is seeking an almost fourfold increase in spending for 1990 on a project to map and sequence the human genome, up from the $\$ 27.6$ million the National Institutes of Health (NIH) will spend on genome activities this year. If this huge increase is approved by Congress it will mean much extra responsibility for the newly christened Program Advisory Committee on the Human Genome, chaired by Norton Zinder of Rockefeller University. NIH are counting on the committee for guidance as they work to sequence the 3,000 million bases that make up the human genome.

NIH director James Wyngaarden gave his agency an active role in the genome project last year when he established NIH's Office of Human Genome Activities and chose as its director James Watson, director of the Cold Spring Harbor Laboratory. The choice of Watson will make it hard for Congress or anyone else to ignore the project. For his part, Watson sees the project as important to the scientific community, not only because of its ultimate goal, but also because it will generate new technology along the way.

Watson's office exists within the office of the director, and does not have legal authority to make grants itself. For the time being it will coordinate its spending choices with the National Institute of General Medical Sciences.

Unlike some advisory groups, Zinder's committee is being urged to take a handson approach as NIH formulate their plans. It will also make up half the membership of a joint committee with the Department of Energy that will coordinate the two agencies' activities as prescribed by a memorandum of understanding signed last autumn.

The National Science Foundation and the Department of Agriculture will also support human genome research, although the Department of Agriculture's contribution will be small, at less than a million dollars. The Howard Hughes Medical Institute will also play an important role in the project, with its support of genetic databases and mapping efforts.

At the advisory committee's first meeting last week, four working groups were set up: one on training chaired by Joseph Goldstein of the University of Texas Southwestern Medical Center in Dallas; one on centres that will work on the pro-

- IN a News item entitled "West Germany voices objections to European genome project" (Nature 336, 416; 1 December 1988), the potential European market for DNA probes should have been given as $1,000-2,000$ million ECU a year. ject co-chaired by Phillip Sharp of the Massachusetts Institute of Technology in Cambridge and Maynard Olson, Washington University School of Medicine, St Louis; another on ethics chaired by Nancy Wexler of Columbia University in New York; and the fourth on databases chaired by David Botstein of Genentech, Inc. in San Francisco.

Olson, who developed the yeast artificial chromosome technology which will probably be used to construct a physical map of the genome, urged the group to pay attention to the issue of resource sharing. Olson says it is difficult to determine how much time individual researchers should be expected to spend in assembling requested resources, even though in principle he believes that reagents developed
Washington

THE US Food and Drug Administration (FDA) last week decided not to add a warning to the labels on birth-control pills after examining new evidence said to link use of the pill to breast cancer. An FDA advisory panel composed of gynaecologists and epidemiologists ruled that data from three independent studies were inconclusive and recommended that more comprehensive studies be conducted before alarming the 13.2 million women in the United States who take the pills.

Earlier studies have uniformly shown that the pill does not increase risk of breast cancer and may even help lower the risk for cancer of the ovaries and uterine lining. The contradictory new data come from a paper by Samuel Shapiro of Boston University to be published in the American Journal of Epidemiology next month, an ongoing study sponsored by the British Royal College of General Practitioners, and a reanalysis of the $\$ 10$ million Cancer and Steroid Hormone (CASH) study sponsored by the US National Institute of Child Health and Human Development.

All three of the studies found the rate of breast cancer increases among young women and women who have been taking birth-control pills for less than ten years. Shapiro's study of 400 women showed that women who have used the pills for less than 10 years had twice the incidence of breast cancer by age 45 than women who did not. The Royal College study led by Clifford Kay, based on data reported by individual physicians on 46,000 women, found no overall increase in cancer among users of the pills, but did find an increase

using public money should be freely available.

While the advisory group is putting together its recommendations, Watson plans to travel around the country, visiting laboratories and talking to university officials. He says that new construction money is needed from Congress to convince universities to act as hosts for genome centres.

Watson believes the entire project can be completed in 15-20 years. A first step will be to upgrade databases containing gene sequences from other organisms, particularly the fruitfly Drosophila, so that human sequence information can be compared to known gene sequences as it is obtained.

A complete physical map of the genome should be complete in 5-7 years, Watson says, although he adds that "Maynard [Olson] looks pained when I say five years because he knows I am counting on him".

Joseph Palca

\title{
FDA sceptical about link between breast cancer and the pill
}

among 30-34-year olds. The reanalysis of the CASH study by Bruce Studel based on 5,600 women shows that childless women with an early menarche who take the pills for more than seven years increase their risk of cancer by 2.7 times.

But each of the studies has technical flaws, and the FDA panel is sceptical of their contradiction of earlier studies which have shown the pills to be safe. The consensus at the FDA meeting was that such surprising increases in breast cancer among younger women could indicate that birth-control pills promote the development of cancer, but do not initiate it. According to Malcolm Potts of Family Health International, if the promoter theory is correct, studies would show increases in the number of young women developing cancer, and drops in the number of post-menopausal women, because women who were already destined to develop cancer would be doing so at an earlier age. The first cohort of women to take the pills are now in their late 40 s, so the predicted dip in the number of cases would not yet have been seen.

A study of 2,000 women which will test this theory has just been launched by the US National Cancer Institute but the results may not be in until the middle of the next decade. The ongoing British study will not receive government funding next year and may be ended.

Health watchdog Sidney Wolfe of the Public Citizen Health Research Group intends to file a petition to require the FDA to reverse its decision not to relabel the pills, and if the agency does not he will bring suit.

Carol Ezzell 